\title{
パラジゥムめっき鉄合金材の耐食性に及ぼす 下地ニッケルめっき析出時のパルス波の効果
}

\author{
珍田 聡*, 吉岡 修*, 小泉 良一** \\ Effect of the Pulse Plating of Nickel-Plated Underlayers \\ on the Corrosion Resistance of Palladium-Plated Ferro-Alloy
}

Akira CHINDA*, Osamu YOSHIOKA* and Ryoichi KOIZUMI**

\begin{abstract}
To prevent the corrosion of palladium-plated ferro-alloy bases for lead frams, the effect of pulse plating on nickel deposits used as the underlayer for palladium-plated layers was investigated.

The following results were obtained.

(1) For nickel deposition at a current density of $4 \mathrm{~A} / \mathrm{dm}^{2}$ and a pulse cycle time of $10 \mathrm{~ms}$, fine crystal grains and a smooth surface were obtained at a duty cycle of $9 \%$.

(2) The nickel underlayers deposited using pulse current at a duty cycle of $9 \%$ improved the corrosion resistance of the palladium-plated ferro-alloy bases more than those deposited using smooth DC. These results suggest the feasibility of applying palladium plating to ferro-alloy lead frames.
\end{abstract}

Key Words : Palladium Plating, Nickel Plating, Pulse Plating, Ferro-Alloy Base, Corrosion Resistance

\section{1. 緒言}

最近，パラジゥムめっきリードフレームが注目されて いる。パラジゥムめっき膜は, 金ワイヤボンディングお よびはんだ付けの双方が可能であるため, ICパッヶー ジの外装はんだめっきが省略できるメリットがある。こ れは組立時間の短縮のみならず，鉛を含む外装はんだが, 鈶公害防止の点から規制されつつある現在，その代替膜 としての適用も考えられている。

前報 ${ }^{1)}$ では, パラジゥムめっきしたリードフレームを 熱処理し，めっき膜特性の変化について詳細に検討した。 その結果, パラジゥムめっきは厚さ $0.05 \mu \mathrm{m}$ 程度で, $300^{\circ} \mathrm{C}, 30$ 秒程度の熱処理にも耐え, 実用上問題のない ことを明らかにした。しかし塩水腐食試験を行ったとこ ろ, 鉄合金の 42 合金材 $(\mathrm{Fe}-40 \mathrm{Ni})$ にパラジゥムめっき を施すと，パラジゥムめっきの下地にニッケルめっきを 約 $1 \mu \mathrm{m}$ 行っても，パラジゥムをカソードとして，素材 が激しい腐食を起こし，実用化が難しいことが分かった。 組立後の ICには，塩水噴霧試験が課せられることが多 いため, 耐塩水腐食性の維持向上は, リードフレーム材 にとって重要な要素である。

鉄合金材は銅合金材よりも剛性が高いため, 多ピン狭

*日立電線(侏) システムマテリアル研究所（テ317 茨城県日立 市助川町 3-1-1)

System's Material Lab., Hitachi Cable, Ltd. (1-1, Sukegawa-cho 3-chome, Hitachi-shi, Ibaraki 317)

** 日立電線(物) 電線工場（テ317 茨城県日立市助川町 3-1-1）

Densen Works, Hitachi Cable, Ltd. (1-1, Sukegawa-cho 3-chome, Hitachi-shi, Ibaraki 317)
ピッチのリードフレーム用材料として需要は高い。一方, パラジゥムめっきははんだブリッジやマイグレーション の心配が無いため, 狭ピッチリードフレームには最適で ある。したがって鉄合金材フレームに，パラジゥムめっ き膜が適用できれば，その効果は極めて大きい。

腐食防止法として, 下地めっきの厚膜化, 高耐食性皮 膜の適用などを検討したが，いずれも十分な効果を上げ ることはできなかった。ニッケルめっきの光沢化す考え られたが, 二ッケルめっき膜中に光沢剤成分の硫黄が包 含されるため，耐食性が劣るとの報告がある ${ }^{2)}{ }^{3)}$ 。と ころでピンホールの少ないめっき膜生成法として，パル スめっき法がしばしば用いられ4),5)，ニッケルめっき

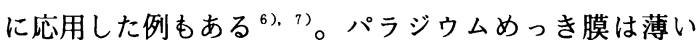
ため, この析出にパルス電流を用いても, 効果は期待し にくい。そこで本報では，下地のニッケルめっき膜にパ ルス法を適用し，42合金材上に種々のパルス電流条件 でニッケルめっきを $1 \mu \mathrm{m}$ 析出させた後に, パラジゥム めっき膜を設け，素材の腐食防止効果について検討した。

\section{2. 実験方法}

\section{1 めっき析出条件}

リードフレーム用鉄合金材である 42 合金板材の全面 に, 表 1 に示す条件で無光沢ニッケルめっき膜を約 $1 \mu \mathrm{m}$ 施し, 次いで日本高純度化学椒パラブライト SST を用いて，パラジゥムめっきを約 $0.1 \mu \mathrm{m}$ 施した。ニッ ケルめっきを行う際に，パルス電流を適用した。パルス 条件を表 2 に記す。なおニッケル，パラジゥムともに， めっき液を機械かく拌させながらめっき膜を析出させた。 
Table 1 Bath composition and plating conditions for nickel plating

\begin{tabular}{lr|ll}
\hline \multicolumn{2}{c|}{ Bath Composition } & \multicolumn{2}{c}{ Plating Conditions } \\
\hline $\mathrm{NiSO}_{4} \cdot 6 \mathrm{H}_{2} \mathrm{O}$ & $240 \mathrm{~g} / \mathrm{L}$ & Temp. & $55^{\circ} \mathrm{C}$ \\
$\mathrm{NiCl}_{2} \cdot 6 \mathrm{H}_{2} \mathrm{O}$ & $40 \mathrm{~g} / \mathrm{L}$ & anode & Ni plate \\
$\mathrm{H}_{3} \mathrm{BO}_{3}$ & $40 \mathrm{~g} / \mathrm{L}$ & Thickness & approx. $1 \mu \mathrm{m}$ \\
\hline
\end{tabular}

Table 2 Pulse plating conditions.

\begin{tabular}{c|c|c|c|c}
\hline $\begin{array}{c}i_{\mathrm{av}} \\
\left(\mathrm{A} / \mathrm{dm}^{2}\right)\end{array}$ & $\begin{array}{c}i_{\mathrm{p}} \\
\left(\mathrm{A} / \mathrm{dm}^{2}\right)\end{array}$ & $\begin{array}{c}t_{\text {on }} \\
(\mathrm{ms})\end{array}$ & $\begin{array}{c}t_{\text {off }} \\
(\mathrm{ms})\end{array}$ & $\begin{array}{c}\text { duty cycle }(\theta) \\
(\%)\end{array}$ \\
\hline 4.0 & 200 & 0.2 & 9.8 & 2 \\
$\uparrow$ & 80.0 & 0.5 & 9.5 & 5 \\
$\uparrow$ & 44.4 & 0.9 & 9.1 & 9 \\
$\uparrow$ & 30.8 & 1.3 & 8.7 & 13 \\
$\uparrow$ & 16.0 & 2.5 & 7.5 & 25 \\
$\uparrow$ & 8.0 & 5.0 & 5.0 & 50 \\
$\uparrow$ & 4.0 & 10.0 & 0 & 100 \\
\hline
\end{tabular}

今回の検討では, 平均電流密度 $4 \mathrm{~A} / \mathrm{dm}^{2}$, パルス 周期 $10 \mathrm{~ms}$ とし，パルス電流印加時間 $\left(t_{\mathrm{on}}\right)$ と電流休止 時間 $\left(t_{\text {off }}\right)$ を変化させて, 周期に占める印加時間の割合 (duty cycle)を 2 〜 $100 \%$ とした。なお $100 \%$ とは，平 滑直流を意味する。パルス電源は, 北斗電工侏カレント パルスジェネータ HC-113を用いた。パラジゥムめっ き条件は前報”と同様であり，またパラジウムめっき析 出時の電流は平滑直流である。

42 合金材の大きさは, 分極曲線測定用は $3 \times 80 \times 0.15$ $\mathrm{mm}^{\mathrm{t}}$ ，浸せき腐食試験用は $30 \times 40 \times 0.15 \mathrm{~mm}^{\mathrm{t}}$ とした。

\section{2 耐食性}

下地ニッケルめっき析出時に, パルス電流条件を変化 させて作製したパラジゥムめっき材の耐食性評価は，了 ノード分極曲線測定と浸せき試験により行った。

分極曲線測定用作用極として, $3 \times 80 \mathrm{~mm}$ の 42 合金材 にめっきしたサンプルを, PET(ポリエチレンテレフタ レート)製マスキングテープで被覆し，表面積 $10 \mathrm{~mm}^{2}$ のみを露出させた微小電極を準備した。そして $25^{\circ} \mathrm{C}$ の $0.01 \mathrm{~mol} / \mathrm{dm}^{3}$ 食塩水中で, 自然電極電位加ら電位掃引 速度 $20 \mathrm{mV} / \mathrm{min}$ で，アノード分極曲線を測定した。

浸せき試験は, $0.05 \mathrm{~mol} / \mathrm{dm}^{3}$ の食塩水を満たした小 型圧力容器 (容積 $70 \mathrm{~mL}$ )に $30 \times 40 \mathrm{~mm}$ のめっき材を入れ て密閉し, $121^{\circ} \mathrm{C}$ 恒温槽中で 24 時間保持した後に, 外観 観察を行った。また素材の 42 合金がニッケルめっき膜 を通して腐食すると，食塩水中に 42 合金の成分である 鉄が溶出するため，その量を分析することで，腐食量の 半定量化を図った。分析手順は, 24 時間浸せき試験終 了後, めっき材を取り出してから, 容器内の食塩水を $300 \mathrm{~mL}$ コニカルビーカに移し，これに濃硝酸を約 10 $\mathrm{mL}$ 加えて加熱し, 固形分すすべてイオン化した。そし てメスアップし, 適度に希釈してから, 原子吸光法で鉄 の定量を行った。

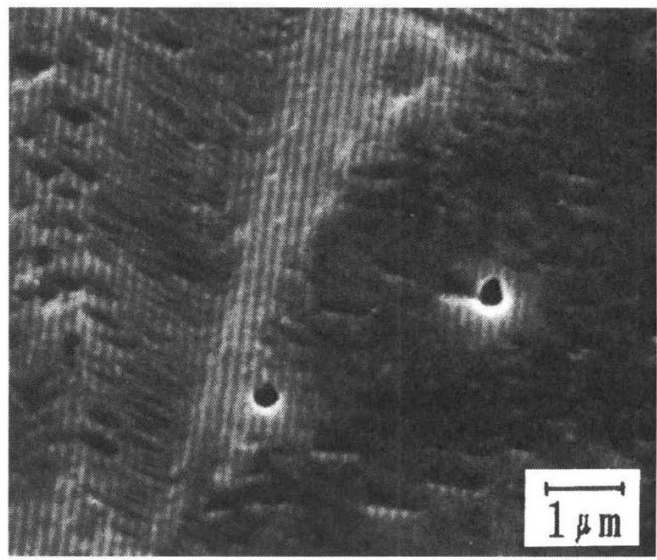

Fig. 1 SEM photograph of the surface of 42alloy base material.

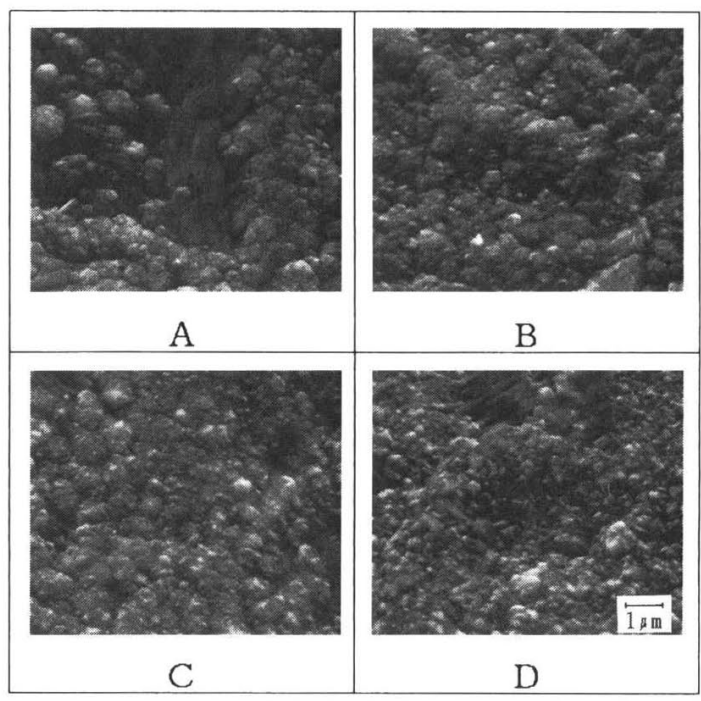

Fig. 2 SEM photographs of the nickel plating surface deposited with various pulse plating conditions.

A ; $\theta=2 \%$, B ; $\theta=9 \%, C ; \theta=25 \%$.

$\mathrm{D} ; \theta=100 \%$

\section{3. 結 果}

\section{1 ニッケルめっき膜の特性}

パルス電流を用いて，42 合金上に析出させたニッケ ルめっき膜の特性を検討した。まず初めに, ニッケルめっ き面のSEM観察を行った。図 1 は, めっきを行う前の 42 合金素材面の SEM写真である。

種々の duty cycleのパルス波を用いて, ニッケルを 約 $1 \mu \mathrm{m}$ 析出させためっき表面の SEM写真を図 2 に示 す。

duty cycle $2 \%(\mathrm{~A})$ では, ニッケルめっきが樹枝状と なり，いわゆる焼けめっき状態となった。これはピーク 


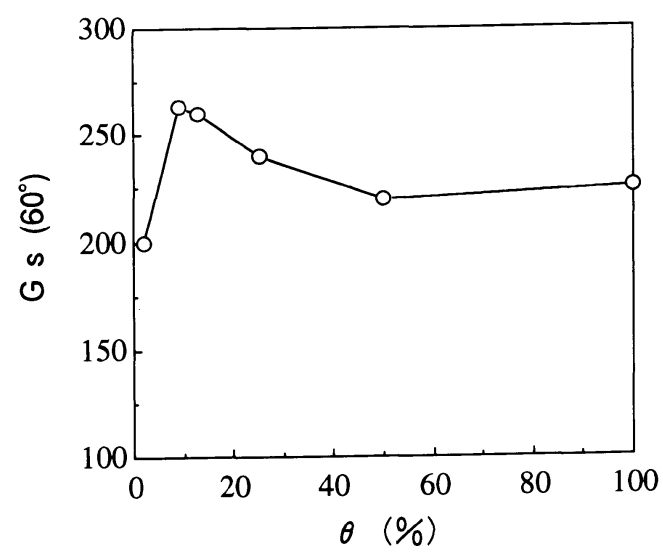

Fig. 3 Relationship between the duty cycle of pulse current and the gross value of nickel plating surface.

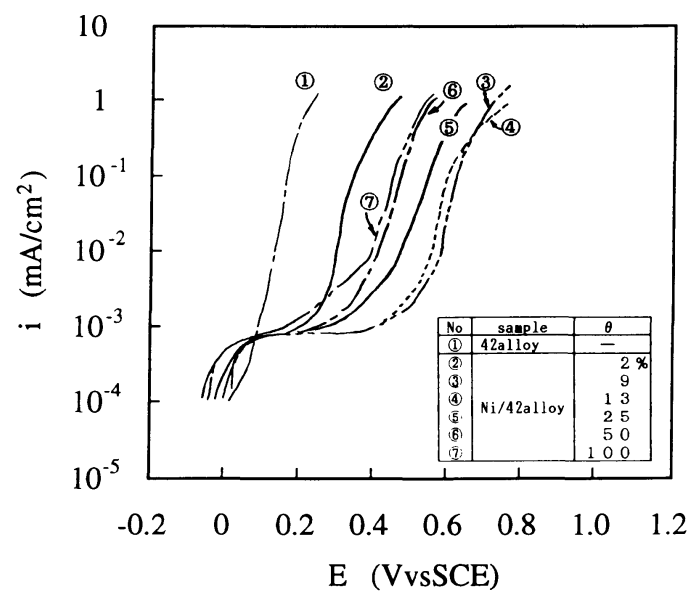

Fig. 4 Polarization curves of nickel plated 42alloy base deposited by various pulse plating conditions.

電流密度が $200 \mathrm{~A} / \mathrm{dm}^{2}$ にあ達するためである。duty cycle 9\%(B)のパルス波で作製したニッケルめっきは, 結晶がち密で，全体に平滑であることが示された。25\% (C) では, 大きく丸みのある結晶と小さな結晶の混在が 観察された。平滑直流の $100 \%(\mathrm{D})$ でニッヶルめっきを行 うと, 細かい角状の結晶形態となった。

これらのニッケルめっき面の光沢度を測定した。使用 機器は村上色彩技術研究所(株)グロスメータ GM-26Dで, 入反射角は $60^{\circ}$ とした。ニッケルめっき析出時のパルス 波の duty cycle とニッケル面の光沢度の関係を図 3 に 示す。この結果加らも, duty cycle $9 \%$ 程度で, 光沢 度が最も高くなり，めっき面が平滑になることが裏付け られた。

次に 42 合金材に, 表 2 に示すパルス条件で, ニッケ ルめっきを施したサンプルの分極曲線を測定し, 結果を

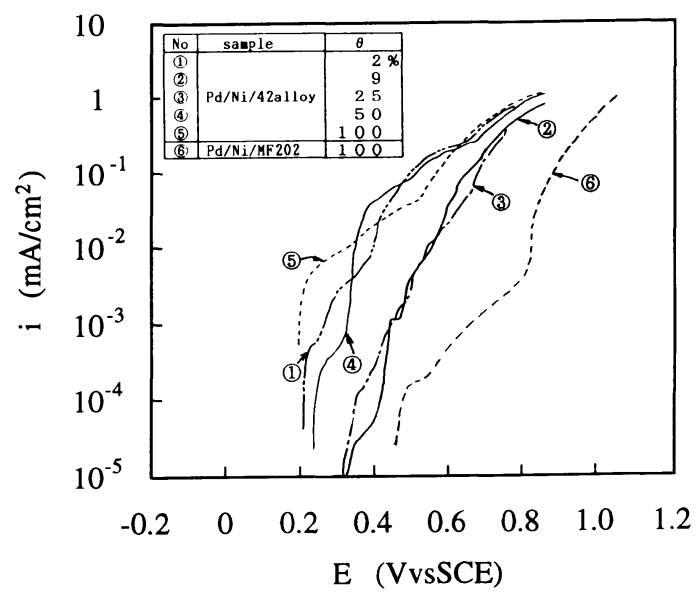

Fig. 5 Polarization curves of palladium plated base with nickel underlayer deposited by various pulse plating conditions.

図4に示した。duty cycle 9および13\%のパルス波を 用いて作製しためっき材(3)，(4)）は，電流の立ち上がる 電位が貴な方向に移行し, 検討したニッケルめっき材の 中では，最も耐食性に優れたものであることが分かった。 すなわち, これらの条件でめっきしたニッケルめっきは, 結晶粒がち密であることは, SEM観察および光沢度の 測定から明らかであり，このために 42 合金素材の, ニッ ケルめっき層を介しての腐食が起こりにくくなるあのと 考えられる。

\section{2 パラジゥムめっき材の涌食性}

パルス波の duty cycleを变えて作製したニッケルめっ き膜の上に，パラジゥムめっき膜を約 $0.1 \mu \mathrm{m}$ 施し，耐 食性について検討した。

分極曲線測定結果を図 5 に示す。参考のために，銅合 金材の MF-202(Cu-2Sn-0.2Ni-0.1Zn)に平滑直流でニッ ケルめっきを施した後に，パラジゥムめっきを行ったサ ンプルの測定結果も示した。最も耐食性の良好なサンプ ルは，銅合金材にめっきを施したあの(6)であるが，下 地ニッケルめっきの析出に duty cycle 9\%(2) または 25\%(3)のパルス波を用いためっき材も，平滑直流で作 製しためっき材(5))より，めっき膜を介しての 42 合金 素材の腐食速度が小さくなることが認められた。この結 果は, 図 4 のニッケルめっき 42 合金材の分極曲線測定 結果と合致した。

浸せき腐食試験後のパラジウムめっき材の外観写真を 図6に示す。下地ニッケルめっき析出時に, duty cycle 9\%のパルス波を用いた板材(B) は, 他の板材に比べて, 著しく腐食しにくいことが, 試料面外観の比較から明ら かである。

図 7 は，浸せき試験後の食塩水中の鉄量を測定した結 果である。duty cycle $9 \%$ の時に，鉄溶出量が最あ少 


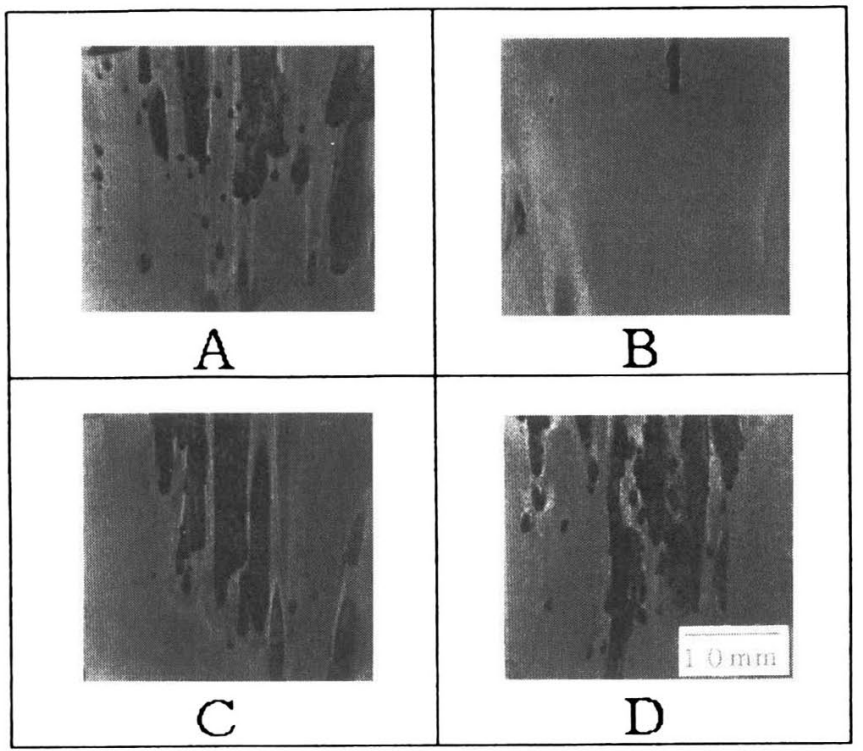

Fig. 6 Surface states of palladium plated base with nickel underlayer deposited by various pulse plating conditions after immersion in $0.05 \mathrm{~mol} /$ $\mathrm{dm}^{3}$ of $\mathrm{NaCl}$ solution. $\left(121^{\circ} \mathrm{C}, 2 \times\right.$ $\left.10^{5} \mathrm{~Pa}, 24 \mathrm{~h}\right)$

A ; $\theta=2 \%$, B ; $\theta=9 \%$,

C ; $\theta=25 \%, D ; \theta=100 \%$

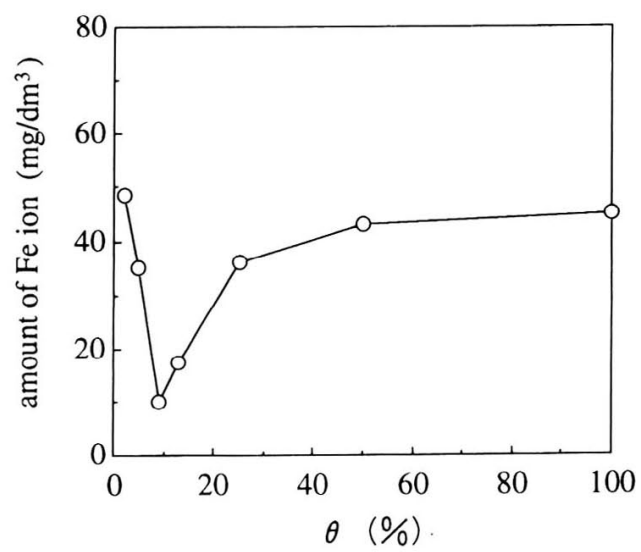

Fig. 7 Relationship between the duty cycle of pulse current and the amount of $\mathrm{Fe}$ ion from plladium plated 42 alloy base with nickel underlayer after immersion in $0.05 \mathrm{~mol} / \mathrm{dm}^{3}$ of $\mathrm{NaCl}$ solution. $\left(121^{\circ} \mathrm{C}, 2 \times 10^{5} \mathrm{~Pa}, 24 \mathrm{~h}\right)$

ないことが示されている。したがってこのパルス条件で 下地ニッケルめっき膜を析出させることにより, パラジ ウムめっきを施した鉄合金材が腐食しにくくなることが, 塩水腐食試験後の食塩水の分析結果からあ明らかになっ た。

以上の結果から, 下地ニッケルめっき析出時に, 適切 な条件のパルス波を用いれば，結晶がち密で平滑なめっ き膜が析出し，このためにニッケルめっきの上にパラジ ウムめっきを施しても, 電位差に基づく素材の腐食が著 しく抑制されることが分かった。銅合金材を用いためっ き材に比較すると, 耐食性はやや少るため, 実用上の効 果は,リードフレームにめっきを施し, 実際にICの組 立を行った上で確認しなければならず，またパルス電流 の周期の影響については, 今後検討の予定であるが, 本
研究内容は, 鉄合金材へのパラジゥムめっき皮膜の適用 に向けて，前進する技術であると確信する。

\section{4. 結言}

パラジゥムめっき膜を鉄合金材に適用する上で，素材 腐食が問題となっている。これを防止するため, パラジ ウムめっきの下地ニッケルめっきにパルス波を適用し, その効果について検討した結果，以下の知見を得た。 (1) ニッケルめっき析出の平均電流密度を $4 \mathrm{~A} / \mathrm{dm}^{2}$, パ ルス電流の周期を $10 \mathrm{~ms}$ 一定とし, duty cycle を変化 させた結果， $9 \%$ の時に二ッケルめっきは，ち密かっ平 滑な結晶形態となることが分かった。

(2) 平滑直流で析出させたニッケルめっき膜に比べて, duty cycle $9 \%$ のパルス電流を用いると, 厚さ $1 \mu \mathrm{m}$ 程 度でも，42合金材の腐食防止効果が著しく向上し，パ ラジゥムめっきの下地めっきとして最適であることを見 出した。

(3) 本研究成果は, パラジウムめっき膜の鉄合金材への 適用の可能性を示唆するすのである。

(Received February 2, 1994 ; Accepted April 11, 1994)

\section{文献}

1) 珍田 聡, 吉岡 修, 小泉良一; 表面技術, 44, 1154 (1993)

2）日本プレーティング協会編；実用めっき I, p.120（槙書店, 1983)

3）柌咱義一 他編；表面技術総覧，p.311（広信社，1983）

$4 ）$ 山下嗣人，伊藤政昭; 金属表面技術，39，219（1988）

5 ）岩城泰彦，荒巻芳幸; 金属表面技術，39，221（1988）

6 ) B. Sutter, F. Mortier, M. A. Lorodre, J. Reby, G. Vasseus ; Proc., Interfinish '84 (1984)

7) F. Mortier ; Cetim-Informations, 72, 21 (1981) 